\title{
Gambaran Kepuasan Pasien dalam Pelayanan Kesehatan \\ Di Puskesmas Atambua Selatan \\ Nusa Tenggara Timur
}

\author{
Oleh \\ Selviana Indah Permata Betten ${ }^{1)}$ \\ Christina Anugrahini ${ }^{2)}$ \\ Melkianus Ratu ${ }^{3)}$
}

1) 2) 3) Program Studi Keperawatan Universitas Timor, Jln Wehor Kabuna Haliwen Atambua, Nusa Tenggara

Timur. Post 85711. Email: akperbelu@gmail.com

Kepuasan Pasien adalah suatu tingkat kepuasan pasien yang timbul sebagai akibat dari kinerja pelayanan kesehatan yang diperolehnya setelah pasien membandingkan dengan apa yang diharapkannya. Penelitian ini menggunakan metode deskriptif. Sampel 67 responden. Analisis data menggunakan uji univariat. Hasil penelitian $100 \%$ responden menyatakan puas berdasarkan tingkat harapan dan 58,2\% responden menyatakan puas berdasarkan tingkat kenyataan sedangkan $41,8 \%$ responden menyatakan kurang puas. Saran : agar pihak puskesmas perlu memperhatikan kelengkapan peningkatan sarana dan prasana yang ada di Puskesmas sebagai upaya peningkatan pelayanan keperawatan.

Kata Kunci : kepuasan pasien, pelayanan kesehatan

\section{Description of patient satisfaction in nursing services at South Atambua Puskesmas East Nusa Tenggara}

\author{
By \\ Selviana Indah Permata Betten ${ }^{1)}$ \\ Christina Anugrahini ${ }^{2)}$ \\ Melkianus Ratu ${ }^{3)}$ \\ 1) 2) 3) Nursing Program at University of Timor, Jl. Wehor Kabuna Haliwen Atambua, East Nusa Tenggara. \\ Post 85711. Email: akperbelu@ gmail.com
}

Patient satisfaction is a level of patient satisfaction that arises as a result of the helath service performance it receives after the patient compares with what is expected. This research uses a descriptive method. Sample cinsist of 67 respondents. Data analysis using univariate test. The result of $100 \%$ of respondents expresed satisfaction on the expectation level and $58,2 \%$ of respondents stated satisfied based on reality level while $41,8 \%$ of respondents said less satisfied. Suggestion : to the puskesmas need to pay attention to the completeness of improvement of facilities and infrastructure that exist in puskesmas as effort of improvement of service of nursing.

Key Words : patient satisfaction, health care

\section{PENDAHULUAN}

Kepuasan pengguna jasa pelayanan kesehatan merupakan selisih kinerja institusi pelayanan kesehatan dengan harapan pasien atau sekelompok masyarakat (Muninjaya, 2011).
Pengukuran kepuasan pengguna jasa kesehatan merupakan salah satu indikator untuk mengetahui mutu pelayanan kesehatan, yaitu layanan kesehatan yang dibutuhkan, dalam hal ini akan ditentukan oleh profesi tenaga kesehatan, dan sekaligus diinginkan baik oleh 
pasien/konsumen ataupun masyarakat serta terjangkau oleh daya beli masyarakat.

Pengukuran kepuasan pengguna jasa kesehatan merupakan salah satu indikator untuk mengetahui mutu pelayanan kesehatan, yaitu layanan kesehatan yang dibutuhkan, dalam hal ini akan ditentukan oleh profesi tenaga kesehatan, dan sekaligus diinginkan baik oleh pasien/konsumen ataupun masyarakat serta terjangkau oleh daya beli masyarakat. Kepuasan pasien merupakan perasaan seorang atau puas bahwa produk atau jasa yang diterima telah sesuai atau melalui harapan pelanggan (Nursalam,2014: 127 ).

Menurut Departemen Kesehatan Republik Indonesia tahun 2013, untuk meningkatkan pelayanan kesehatan pemerintah telah membangun sarana pelayanan kesehatan dasar di Indonesia yaitu terdapat 9.599 puskesmas, 23.875 puskesmas pembantu yang didukung 8.009 puskesmas keliling. Saat ini distribusi puskesmas dan puskesmas pembantu sebagai ujung tombak pelayanan kesehatan dasar telah lebih merata. Setiap puskesmas melayani 30.000 - 50.000 penduduk atau sekurang-kurangnya 1 kecamatan mempunyai sati puskesmas. Untuk memperluas jangkauan layanan kesehatan, setiap puskesmas dibantu oleh 3-4 puskesmas pembantu dan satu puskesmas keliling (Depkes, RI. 2003 : dalam Hufron, 2008). Survei kepuasan pasien menurut Setyawati, et al (2003) terkait dengan banyaknya pasien yang memilih rawat jalan termasuk puskesmas dan puskesmas pembantu di Sumatera, Jawa, Bali, kawasan timur Indonesia sebesar 23,5\% memilih rawat jalan di puskesmas dan 9,9\% memilih rawat jalan di puskesmas pembantu. Pemanfaatan puskemas sama - sama diminati penduduk di pedesaan maupun di perkotaan. Hasil survei yang dilakukan oleh Tim Quality Assurance Puskesmas Penumping di Surakarta. Pada awal tahun 2006 tentang kepuasan pasien yang berkunjung dipuskesmas menunjukkan hasil bahwa $3 \%$ pasein menyatakan tidak puas, dan masih ada $21 \%$ pasein kurang puas atas pelayanan yang diberikan, $49 \%$ pasien menyatakan cukup puas, dan $17 \%$ pasien puas terhadap pelayanan puskesmas. Dalam rekapitulasi kunjungan puskesmas penumping surakarta tahun 2005 mengalami penurunan dibandingkan dengan tahun 2004 yaitu sebesar 53.578 pasien (rata - rata 172 pasien / hari), menjadi 53.368 pasien (rata - rata 171 pasien / hari) pada tahun 2005. Berdasarkan survei awal yang dilakukan di Puskesmas Atambua Selatan jumlah pasien yang berobat ke Puskesmas tersebut 27 Orang/hari sedangkan pertahunnya sekitar 8.559 Orang. (Puskesmas Atambua Selatan, 2017).

\section{METODE PENELITIAN}

penelitian ini penulis menggunakan pendekatan kuantitatif dengan metode deskriptif dengan tujuan untuk mengekspresikan kepuasan pasien dalam pelayanan kesehatan. Populasi dalam penelitian ini adalah semua pasien yang berobat ke puskesmas Atambua Selatan Nusa Tenggara Timur, terhitung mulai 27 Februari - 09 Maret dengan jumlah 67 Orang.

Sampel Penelitian ini menggunakan Teknik Sampling yang yang digunakan dalam 
pengambilan sampel adalah Quota sampling. Quota sampling adalah teknik untuk menentukan sampel dari populasi yang mempunyai ciri - ciri tertentu sampai jumlah (Kuota) yang diinginkan (Sugiyono, 2008). Metode pengumpulan data yang digunakan adalah kuesioner.

Analisa Data

Hastono (2007) dalam Anugrahini (2010) mengemukakan bahwa tujuan analisis ini adalah untuk mendeskripsikan karakteristik masing masing variabel yang teliti. Bentuknya tergantung dari jenis dataya, untuk data numerik digunakan nilai mean (rata - rata), median, dan standar deviasi. Data kategori yaitu menjelaskan angka atau nilai jumlah dan presentase masing masing kelompok.

Selanjutnya hasil untuk mengetahui kepuasan pasien dan jumlah pasien menurut kepuasan pasien maka, ditunjukkan dengan presentase melalui perbandingan antara harapan dan kenyataan dengan kriteria penilaian sebagai berikut :

1. Puas : kenyataan $\geq$ harapan

2. Kurang puas : kenyataan $<$ harapan

\section{HASIL DAN PEMBAHASAN}

\section{Hasil}

a. Karakteristik Responden

1. Jenis Kelamin

Tabel 1

Distribusi Responden Berdasarkan Jenis

Kelamin di Puskesmas Atambua

Selatan Tahun 2018

\begin{tabular}{cccc}
\hline & Jenis & Frekuensi & Persentase \\
No & Kelamin & $(\mathrm{f})$ & $(\%)$ \\
\hline
\end{tabular}

\begin{tabular}{lllc}
\hline 1 & Laki-laki & 29 & 43,3 \\
2 & Perempuan & 38 & 56,7 \\
& Jumlah & 67 & 100 \\
\hline Tabel & 1 & menunjukkan & responden laki - laki \\
lebih & sedikit dari responden perempuan. Yakni \\
responden laki - laki & 29 & orang $\quad(43,3 \%)$ \\
sedangkan responden perempuan sebanyak 38 \\
orang $(56,7 \%)$.
\end{tabular}

2. Umur

Tabel 2

Distribusi Responden Berdasarkan Usia di Puskesmas Atambua Selatan

Tahun 2018

\begin{tabular}{|c|c|c|c|}
\hline No & Umur & $\begin{array}{l}\text { Frekuensi } \\
\text { (f) }\end{array}$ & $\begin{array}{c}\text { Persentase } \\
(\%)\end{array}$ \\
\hline 1 & $\begin{array}{c}17-24 \\
\text { thn }\end{array}$ & ( & 11,9 \\
\hline 2 & $\begin{array}{c}25-34 \\
\text { thn }\end{array}$ & 17 & 25,4 \\
\hline 3 & $\begin{array}{c}35-49 \\
\text { thn }\end{array}$ & 21 & 31,3 \\
\hline 4 & $\begin{array}{c}50-64 \\
\text { thn }\end{array}$ & 14 & 20,9 \\
\hline \multirow[t]{2}{*}{5} & $\begin{array}{l}65 \text { thn } \\
\text { keatas }\end{array}$ & 7 & 10,5 \\
\hline & Jumlah & 67 & 100 \\
\hline
\end{tabular}

Tabel 2 menunjukkan bahwa kelompok umur responden yang tertinggi adalah 35 - 49 tahun sebanyak 21 orang $(31,3 \%)$ dan terendah adalah kelompok 65 tahun keatas sebanyak 7 orang $(10,5 \%)$.

\section{Pekerjaan}

Tabel 3

Distribusi Responden Berdasarkan Jenis Pekerjaan di Puskesmas Atambua Selatan Tahun 2018

\begin{tabular}{cccc}
\hline No & Pekerjaan & $\begin{array}{c}\text { Frekuensi } \\
(\mathbf{f})\end{array}$ & $\begin{array}{c}\text { Persentase } \\
(\mathbf{\%})\end{array}$ \\
\hline 1 & $\begin{array}{c}\text { Pelajar } / \\
\text { Mahasiswa } \\
\text { Tidak }\end{array}$ & 7 & 10,5 \\
2 & $\begin{array}{c}\text { bekerja } \\
\text { bekis }\end{array}$ & 24 & 35,8
\end{tabular}




\begin{tabular}{cccc}
3 & Pegawai & & \\
4 & swasta & 9 & 13,4 \\
5 & Buruh & 4 & 6 \\
5 & Pedagang & 9 & 13,4 \\
& Pegawai & & \\
6 & Negeri & 14 & 20,9 \\
& Jumlah & 67 & 100 \\
\hline
\end{tabular}

Tabel 3 menunjukkan bahwa pekerjaan responden yang tertinggi adalah tidak bekerja sebanyak 24 orang $(35,8 \%)$ sedangkan yang sedikit adalah buruh sebanyak 4 orang $(6 \%)$.

b. Analisa Univariat

1. Distribusi Harapan Responden dalam Pelayanan Kesehatan

Tabel 4

Distribusi Harapan Responden dalam Pelayanan Kesehatan di Puskesmas Atambua Selatan Tahun 2018

\begin{tabular}{cccc}
\hline No & Kategori & $\begin{array}{c}\text { Frekuensi } \\
(\mathbf{f})\end{array}$ & $\begin{array}{c}\text { Presentase } \\
(\mathbf{\%})\end{array}$ \\
\hline 1 & Tinggi & 105 & 100 \\
2 & Rendah & 0 & 0 \\
& Jumlah & 105 & 100 \\
\hline
\end{tabular}

Tabel 4 menunjukkan bahwa harapan responden dalam pelayanan kesehatan adalah kategori tertinggi 105 (100\%).

2. Distribusi kenyataan dalam Pelayanan Kesehatan berdasarkan presepsi pasien

Tabel 5

Distribusi Harapan Responden dalam Pelayanan kesehatan di Puskesmas Atambua Selatan Tahun 2018

\begin{tabular}{cccc}
\hline No & Kategori & $\begin{array}{c}\text { Frekuensi } \\
(\mathbf{f})\end{array}$ & $\begin{array}{c}\text { Presentase } \\
(\mathbf{\%})\end{array}$ \\
\hline 1 & Tinggi & 105 & 59,6 \\
2 & Rendah & 71 & 40,4 \\
& Jumlah & 176 & 100 \\
\hline
\end{tabular}

Tabel 5 menunjukkan bahwa kenyataan pelayanan kesehatan berdasarkan presepsi pasien adalah kateogri tertinggi $105(59,6 \%)$ dan katgori terendah $71(40,4 \%)$.

3. Distribusi kepuasan setelah membandingkan antara harapan dan kenyataan pasien dalam Pelayanan Kesehatan

Tabel 6

Distribusi Kepuasan setelah membandingkan antara dalam harapan dan kenyataan Pasien dalam Pelayanan kesehatan Di Puskesmas Atambua Selatan Tahun 2018

\begin{tabular}{cccc}
\hline No & $\begin{array}{c}\text { Pelayanan } \\
\text { Kesehatan }\end{array}$ & $\begin{array}{c}\text { Frekuensi } \\
(\mathbf{f})\end{array}$ & $\begin{array}{c}\text { Presentase } \\
(\boldsymbol{\%})\end{array}$ \\
\hline 1 & Puas & 5 & 7,5 \\
2 & Kurang Puas & 62 & 92,5 \\
& Jumlah & 67 & 100 \\
\hline
\end{tabular}

Tabel 6 menunjukkan bahwa kepuasan setelah membandingkan antara harapan dan kenyataan pasien dalam pelayanan kesehatan yakni yang menyatakan puas sebanyak $5 \quad(7,5 \%)$ responden dan menyatakan kurang puas sebanyak 62 $(92,5 \%)$ responden.

\section{Pembahasan}

a. Penilaian harapan responden dalam pelayanan kesehatan

Bedasarkan hasil penelitian harapan responden adalah kategori tertinggi adalah $105(100 \%)$ dalam pelayanan kesehatan yang diberikan di Puskesmas Atambua Selatan.

Berdasarkan teori, Menurut Leonard L. Barry dan Pasuraman “ marketing servis 
competin through quality " (New Freepress, 1991) yang dikutip (Kotler, 2000 dalam Nursalam, 2011) dan jurnal Nur Yanti (2013) mengidentifikasi lima dimensi dalam pelayanan keperawatan yaitu tangibles (nyata) yang meliputi penampilan fasilitas dan peralatan materi komunikasi yang menarik, empati yang meliputi sifat dan kemampuan untuk memberikan perhatian penuh kepada pasien, reliability (keandalan) yaitu kemampuan perawat memberikan pelayanan yang dijanjikan segera, responsive (ketanggapan) yaitu keinginan para perawat dalam memberikan pelayanan yang tanggap, asurance (kepastian) yaitu kompetensi yang dimiliki sehingga memberikan rasa aman bebas dari bahaya, resiko, atau keraguan dan kepastian yang mencakup pengetahuan.

Menurut peneliti bahwa responden mengharapkan pelayanan yang memuaskan. Jika pelayanan tidak sesuai dengan apa yang responden harapkan maka akan berdampak pada perasaan ketidakpuasan responden.

b. Penilaian kenyataan dalam pelayanan kesehatan berdasarkan presepsi pasien

Berdasarkan hasil penelitian kenyataan dalam pelayanan kesehatan berdasarkan presepsi pasien kategori tertinggi adalah $105(59,6)$ dan kategori terendah $71(40,4)$ di Puskesmas Atambua Selatan.

Berdasarkan teori, Menurut Leonard L. Barry dan pasuraman “ marketing servis competin through quality " (New
Freepress, 1991) yang dikutip (Kotler, 2000 dalam Nursalam, 2011) dan jurnal Nur Yanti (2013) mengidentifikasi lima kelompok yaitu tangibles (nyata) yang meliputi penampilan fasilitas dan peralatan materi komunikasi yang menarik, empati yang meliputi sifat dan kemampuan untuk memberikan perhatian penuh kepada pasien, reliability (keandalan) yaitu kemampuan perawat memberikan pelayanan yang dijanjikan segera, responsive (ketanggapan) yaitu keinginan para perawat dalam memberikan pelayanan yang tanggap, asurance (kepastian) yaitu kompetensi yang dimiliki sehingga memberikan rasa aman bebas dari bahaya, resiko, atau keraguan dan kepastian yang mencakup pengetahuan.

Menurut Peneliti bahwa ketika pelayanan kesehatan tidak memuaskan responden maka akan menghasilkan ketidakpuasan. Hal ini sangat jelas bahwa apabila pelayanan kesehatan kurang baik maka akan berdampak terhadap kepuasan pasien.

c. Penilaian kepuasan setelah membandingkan antara harapan dan kenyataan pasien dalam pelayanan kesehatan

Berdasarkan hasil penelitian responden yang menyatakan puas sebanyak $5(7,5 \%)$ responden dan responden yang menyatakan kurang puas adalah $62 \quad(92,5 \%) \quad$ di Puskesmas Atambua Selatan. Hasil penelitian ini tidak sesuai dengan peneliti sebelumnya yang dilakukan oleh Jusriani (2016) didapatkan data dimana 30 
responden $(30 \%)$ menyatakan cukup puas dan 70 responden (70\%) menyatakan kurang puas. Hasil penelitian ini mau menjelaskan bahwa pelayanan kesehatan memegang peranan penting dalam kepuasan pasien.

Berdasarkan teori, menurut Pohan (2003, hh : 178 - 179) menyatakan bahwa kepuasan pasien adalah suatu tingkat kepuasan pasien yang timbul sebagai akibat dari kinerja pelayanan kesehatan yang diperolehnya setelah pasien membandingkan dengan apa yang diharapkanya (Arifin, 2013).

Menurut Peneliti bahwa ketika pelayanan kesehatan tidak memuaskan responden maka akan menghasilkan ketidakpuasan. Hal ini sangat jelas bahwa apabila pelayanan kesehatan kurang baik maka akan berdampak terhadap kepuasan pasien.

\section{Keterbatasan Penelitian}

Peneliti menyadari bahwa penelitian ini masih jauh dari sempurna dan memiliki banyak keterbatasan serta memerlukan perbaikan. Adapun keterbatasan penelitian ini antara lain : Sampel yang digunakan pada penelitian meneliti pasien yang berobat ke Puskesmas Atambua Selatan Kecamatan Atambua Selatan Kabupaten belu dalam Pelayanan Keperawatan, hal ini dipengaruhi oleh faktor keterbatasan waktu, tenaga maupun faktor ekonomi peneliti sehingga hasil yang diperoleh kurang optimal sesuai dengan yang diharapkan. Kuesioner yang peneliti gunakan adalah kuesioner yang diadopsi dari Hidayat (2014).

\section{Kesimpulan}

Berdasarkan hasil penelitian maka dapat dikemukakan kesimpulan yaitu :

a. Harapan pasien dalam pelayanan kesehatan dengan kategori tertinggi adalah 105

b. Kenyataan dalam pelayanan kesehatan berdasarkan presepsi pasien dengan kategori tertinggi adalah 105 dan kategori terendah adalah 71

c. Gambaran kepuasan setelah membandingkan antara harapan dan kenyataan pasien dalam pelayanan kesehatan yakni lebih banyak responden yang menyatakan kurang puas daripada yang menyatakan puas

\section{Referensi}

Arikunto, S. 2006. Prosedur Penelitian : Suatu Pendekatan Praktek, Edisi Ke IV; PT Rineka Cipta, Jakarta.

Bustami, 2011. Penjamin Mutu Pelayanan kesehatan dan Akeptabilitasnya. Jakarta : Erlangga

Depkes RI. 2013. Pedoman Pelaksanaan Jaminan kesehatan masyarakat, Depkes RI. Jakarta 
Hastono, S (2007) dalam Anugrahini, C (2010). Hubungan Faktor Individu Dan Organisasi Dengan Kepatuhan Perawat Dalam Menerapkan Pedoman Patient Safety di RSAB Harapan kita. Universitas Indonesia. Depok

Hastono, Susanto. 2007. Analisis Data Kesehatan. Fakultas Kesehatan Masyarakat Universitas Indonesia

Hidayat, R. 2014 . Kuesioner Kepuasan Pasien. Universitas Sumatera Utara

Muninjaya, G. 2011. Manajemen Mutu Pelayanan Kesehatan. Jakarta : Buku Kedokteran EGC

Natoatmojo, S. 2007. Metedologi Penelitian kesehatan. Jakarta ; Rineka Cipta

Nursalam. (2014). Manajmen keperawatan : Aplikasi dalam Praktik Keperawatan Profesional Edisi 4. Jakarta : Salemba Medika

Nursalam. (2011). Manajamen keperawatan : Aplikasi dalam Praktik Keperawatan Profesional . Jakarta : Salemba Medika

Nursalam, 2008. Konsep dan Penelitian Ilmu Keperawatan. Edisi $2 . \quad$ Jakarta: Salemba Medika

Nur Yanti, 2013. Gambaran Kepuasan Pasien Terhadap Fasilitas dan Pelayanan Keperawatan di Ruang Rawat Inap RSUD ANDI DJEMMA MASAMBA.FIK : Universitas Islam Negeri Alauddin. Makasar

Pohan, I.S. 2003. Jaminan Mutu Layanan Kesehatan : Dasar - dasar Pengertian dan Penerapan. Jakarta : EGC

Sugiyono, 2008. Metode Penelitian Kuantitatif, Kualitatif dan $R \& D$. Bandung : Penerbit Alfabeta
Supranto. 2011. Pengukuran Tingkat Kepuasan Pelanggan. Jakarta : Rineka Cipta

Wijono, Djoko. (2010). Manajemen Mutu Pelayanan Kesehatan : Teori Stratedi dan Aplikasi Vol.1. Jakarta 